\title{
Regulation of dominant follicle turnover during the oestrous cycle in cows
}

\author{
J. D. Savio, W. W. Thatcher*, L. Badinga, R. L. de la Sota and D. \\ Wolfenson $\dagger$
}

Dairy Science Department, University of Florida, Gainesville, FL 32611, USA

\begin{abstract}
The effect of progestin and luteinizing hormone (LH) pulse frequency on dynamics of dominant follicle growth during the first follicular wave after oestrus was examined in nonlactating Holstein cows by ultrasonography. On day 8 of the cycle, cows $(n=8)$ received a luteolytic dose of prostaglandin $\mathrm{F}_{2 \alpha}\left(\mathrm{PGF}_{2 \alpha} ; 25 \mathrm{mg}\right)$ and an ear implant of Norgestomet $(6 \mathrm{mg})$. On day 18 , cows were assigned to a crossover design in which the implants were retained (T1) or replaced with a new implant (T2). All implants were removed on day 23 . After oestrus, cows underwent a normal intervening oestrous cycle. On day 8 of the third cycle, T1 and T2 were reversed among cows. Ultrasonography and blood sampling were performed on alternate days throughout the experiment. On days 10 and 19 of the third cycle, blood was sampled every $15 \mathrm{~min}$ for $8 \mathrm{~h}$ in concert with an additional control group $(n=3)$ sampled on day 10 of the cycle. Progesterone concentration on day 8 before PGF $2 a$ was $6.5 \pm 0.5 \mathrm{ng} \mathrm{ml}^{-1}$. Dominance of the first wave dominant follicle was extended beyond day 18 in 15 of 16 cows for T1 and T2 periods. The original dominant follicle ovulated in five of eight T1 and none of eight T2 periods $(P<0.01)$. New dominant follicles were detected on day $24 \pm 1$ in T1 $(n=3)$ and on day $20.6 \pm 1$ in T2 $(n=8 ; P<0.01)$ cows. Growth rate of the dominant follicle from day $8(15.8 \pm 0.4 \mathrm{~mm})$ to day $18(22.9 \pm 0.6 \mathrm{~mm})$ was $0.7 \mathrm{~mm}$ day $^{-1}(n=15)$. Preovulatory sizes for the initial and new dominant follicles were $26.8 \pm 1 \mathrm{~mm}(n=5)$ and $15.3 \pm 0.8 \mathrm{~mm}(n=11)$, respectively $(P<0.01)$. Intervening oestrous cycles comprised three $(n=5)$ and two $(n=3)$ follicular waves. An interaction of treatment by day $(P<0.01)$ for LH pulses in $8 \mathrm{~h}$ was detected (pulses on days 10 and 19 for $\mathrm{T} 1(5.2 \pm 0.5$ and $7 \pm 0.7)$ versus $\mathrm{T} 2(5.7 \pm 0.5$ and $3 \pm 0.4))$. A mean of $0.7 \pm 0.3 \mathrm{LH}$ pulses in $8 \mathrm{~h}$ was detected on day 10 for control cows $(n=3)$. Increased LH support appears to maintain a dominant follicle, whereas high progesterone concentrations decrease LH pulse frequency leading to turnover of the dominant follicle in cattle.
\end{abstract}

\section{Introduction}

Follicular development in single ovulatory species proceeds through stages of recruitment, selection and dominance (Goodman and Hodgen, 1983; Ireland and Roche, 1987). During the oestrous cycle of cows, follicular growth is characterized by development of one or two dominant anovulatory follicles before maturation of a terminal ovulatory follicle. Development of the first dominant follicle is the most consistent event related to follicular dynamics during the oestrous cycle in heifers and cows. The first dominant follicle can be identified using ultrasonography, retrospectively, between days 2 and 4 of the cycle. This follicle reaches a maximum diameter between days 6 to 8 , maintains this size for a period, and undergoes regression after the emergence of the second follicular wave at about mid-cycle (Savio et al., 1988, 1990a; Sirois and Fortune, 1988; Knopf et al., 1989; Ginther et al., 1989a; Driancourt et al., 1991). Similar and successive (every 10-12 days) waves of follicular development are

${ }^{*}$ Reprint requests.

†Present address: Department of Animal Science, Faculty of Agriculture, Hebrew University, Rohovot 76100, Israel.

Received 20 February 1992. observed during early stages of pregnancy (Ginther et al., 1989b; Savio et al., 1990a; Thatcher et al., 1991).

Dominant follicles apparently control development of other follicles through production of hormones, such as oestradiol, inhibin, activin and follistatin, and other secretory products (growth promoting or inhibiting factors), which may act locally, systemically or both locally and systemically (Ireland and Roche, 1987; Lucy et al., 1992). Inhibin was considered to regulate follicular development by altering the secretion of folliclestimulating hormone (FSH) (Ireland, 1987; Findlay et al., 1990). Any intragonadal action of inhibin has not yet been conclusively documented (Findlay et al., 1990).

Abeyawardene and Pope (1987) proposed that growth of the first dominant follicle of the oestrous cycle in cattle is halted about 2 days before its potential ovulation by the negative feedback effect of progesterone from the corpus luteum on luteinizing hormone (LH) secretion. Ovulation of first wave dominant follicles in heifers after injections of prostaglandin $\mathrm{F}_{2 \alpha}$ $\left(\mathrm{PGF}_{2 \alpha}\right.$ ) on days 5, 7 or 8 of the oestrous cycle (Kastelic et al., 1990; Savio et al., 1990b) support this hypothesis. The first wave dominant follicle is the ovulatory follicle in short ovarian cycles (8-12 days), following a period of anoestrus (Savio et al., 
1990a). LH secretion during the oestrous cycle in cattle is characterized by high frequency, low amplitude LH pulses during pro-oestrus and metoestrus and by low frequency, high amplitude pulses during dioestrus (Rahe et al., 1980; Walters et al., 1984; Schallenberger et al., 1985a). Roberson et al. (1989) and Kojima et al. (1990) reported that exogenous supplemental progestins, administered after $\mathrm{PGF}_{2 \alpha}$-induced luteolysis in cows, resulted in increased $\mathrm{LH}$ pulse frequency in comparison with that in cows with an intact corpus luteum. Detection of higher blood concentrations of oestradiol in animals without a corpus luteum suggests a link between LH secretion and abnormal ovarian follicular activity (Roberson et al., 1989).

The hypothesis that dominant follicle turnover is altered by the progestin Norgestomet was tested by designing an experiment to study ovarian follicular dynamics in cattle in which normal endocrine environments were altered by prostaglandin-induced luteolysis and insertion of implants containing Norgestomet.

\section{Materials and Methods}

\section{Animals and treatments}

Eight nonlactating Holstein cows were kept in pasture lots and received supplementary peanut hay and corn silage. Oestrous cycles were synchronized using a Norgestomet implant (6 mg; Syncro-mate-B: CEVA Laboratories, Inc., Overland Park, $K S$ ) inserted subcutaneously on the outer surface of the ear and left in place for 9 days. In addition, $25 \mathrm{mg}$ of $\mathrm{PGF}_{2 \alpha}\left(\mathrm{PGF}_{2 \alpha}\right.$ tham salt; Lutalyse: Upjohn Co., Kalamazoo, MI) was injected i.m. 2 days before withdrawal of the Norgestomet implant. The day of synchronized oestrus was designated as day 0 . Animals were assigned randomly, according to a crossover design, to either: Treatment I group (TI): a Norgestomet implant was inserted, and $\mathrm{PGF}_{2 \alpha}$ injected ( $25 \mathrm{mg}$, i.m.) on day 8 of the oestrous cycle; the implant was withdrawn on day 23 of the oestrous cycle; or Treatment 2 group (T2): identical to T1, except that the Norgestomet implant inserted on day 8 was replaced with a new implant on day 18 of the oestrous cycle. As in T1, the implant was removed on day 23 . The rationale for implant replacement on day 18 was based on the manufacturer's information that beyond 9 days implants do not consistently suppress oestrus.

After removal of the implant at day 23 and subsequent ovulation, all cows were monitored during an intervening oestrous cycle before entering the second experimental period whereby animals previously in $\mathrm{T} 1$ received $\mathrm{T} 2$ treatment and vice versa. The intervening oestrous cycle permitted an assessment of normal follicular development and the measurement of potential carry-over effects.

\section{Experimental procedures}

Ovarian follicular populations were assessed via ultrasonography using an Equisonics 1000 linear array ultrasound scanner equipped with a $7.5 \mathrm{MHz}$ transrectal transducer (Tokyo Keiki Co. Ltd., Tokyo, Japan). During each examination, ovarian maps were drawn to record size and relative position of follicles $>2 \mathrm{~mm}$ and the presence of corpora lutea (Savio et al., 1988). Ultrasound examinations were performed by the same operator on days $7,8,10,12,14,16,18,20,22$ and 23 and then daily until ovulation occurred for both periods. During the intervening oestrous cycle, follicular dynamics were examined every other day until ovulation. The following follicular responses were evaluated: size of dominant follicle and number of follicles in classes I ( 3 to $4 \mathrm{~mm}$ ), II ( 5 to $9 \mathrm{~mm}$ ) and III ( $\geq 10 \mathrm{~mm}$ ).

Before each session of ultrasonography, blood samples were obtained by jugular venepuncture and stored in an ice bath until centrifugation $(3000 \mathrm{~g}$ for $30 \mathrm{~min}$ ). Plasma was collected and stored at $-20^{\circ} \mathrm{C}$ until assayed for progesterone (Knickerbocker et al., 1986) and oestradiol (Tortonese et al., 1990) as modified by Badinga et al. (1992). Intra- and interassay coefficients of variation were 8 and $11 \%$ for progesterone and 10 and $14 \%$ for oestradiol, respectively. The sensitivity of the assays was $0.1 \mathrm{ng}$ $\mathrm{ml}^{-1}$ for progesterone and $1.4 \mathrm{pg} \mathrm{ml}^{-1}$ for oestradiol.

On days 10 and 19 of the second experimental period, blood samples were taken every $15 \mathrm{~min}$ for $8 \mathrm{~h}$, via an indwelling jugular catheter, to study the pattern of $\mathrm{LH}$ secretion. Three additional nonlactating cows at day 10 of the oestrous cycle were included to provide a normal luteal phase control group for LH pulse measurement. Plasma was separated by centrifugation at $3000 \mathrm{~g}$ for $30 \mathrm{~min}$ within $15 \mathrm{~min}$ of sampling and stored at $-20^{\circ} \mathrm{C}$ until assayed for LH. LH was assayed using a validated radioimmunoassay (Lucy ef al., 1991); intra- and interassay coefficients of variation were 2 and $7 \%$, respectively. The sensitivity of the assay was $0.1 \mathrm{ng} \mathrm{ml}^{-1}$. An LH pulse was defined as an abrupt increase in hormone concentration (peak) which exceeded the previous sample (basal) by at least four times the coefficient of variation of the assay and had one or more values on the decreasing slope (Walters et al., 1984). Amplitude was calculated as the difference between the peak and the preceding nadir.

\section{Statistical analysis}

Data were analysed statistically using the General Linear Model procedure of the Statistical Analysis System (SAS, 1987). The size of the dominant follicle and the plasma concentrations of progesterone and oestradiol, as well as the total number of follicles classified by size (class I, 3-4 mm; class II, 5-9 mm and class III, $>9 \mathrm{~mm}$ ) were analysed using a mathematical model that examined the effects of treatment, cow, period, day and higher order interactions. Differences between means were evaluated by preplanned orthogonal contrasts. Proportional responses were compared using $\chi^{2}$ analysis.

\section{Results}

\section{Progesterone concentrations}

Plasma concentrations of progesterone declined significantly $(P<0.05)$ after day 8 of the oestrous cycle following injection of $\mathrm{PGF}_{2 \alpha}$ and remained at a low basal concentration throughout the experimental period (about $0.3 \mathrm{ng} \mathrm{ml}^{-1}$ ) in both treatment groups.

\section{Follicular development}

The first dominant follicle of the oestrous cycle was identified in all animals at the ultrasound examination carried out on 

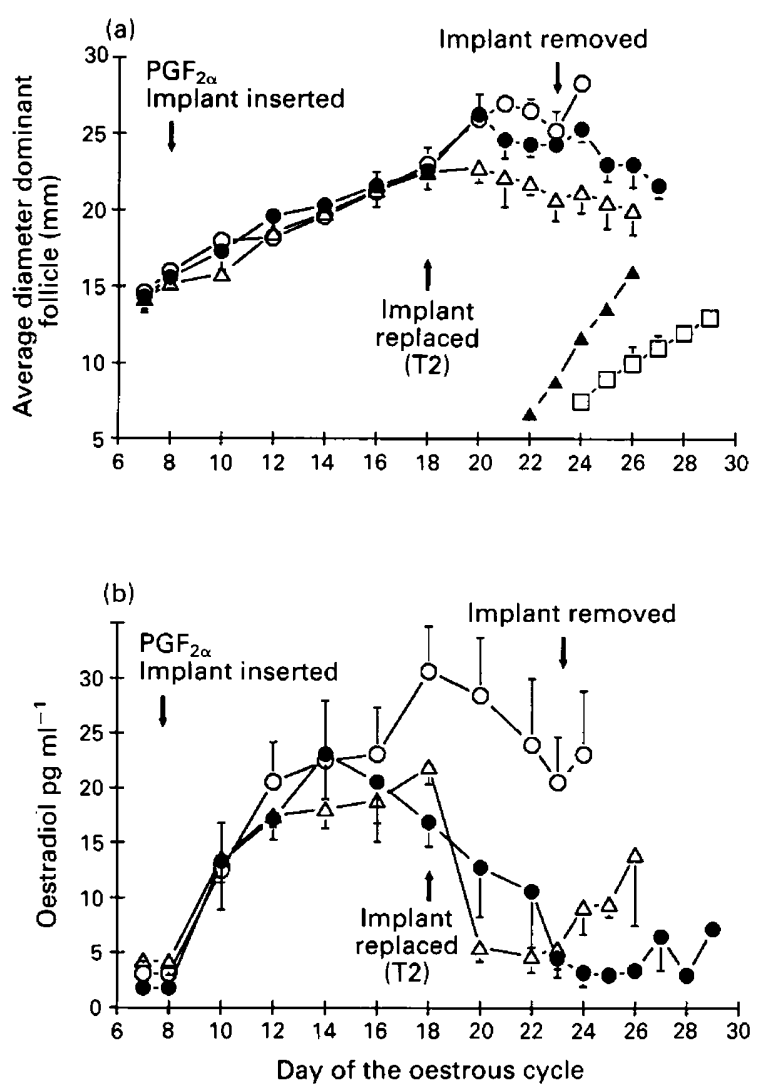

Fig. 1. Average diameter of the dominant follicles and plasma concentrations of oestradiol during the experimental oestrous cycles in nonlactating Holstein cows that received a $\mathrm{PGF}_{2 \alpha}$ injection $(25 \mathrm{mg})$ and a Norgestomet implant $(6 \mathrm{mg})$ on day 8 of the oestrous cycle. The initial Norgestomet implant was replaced with a new unit on day 18 in T2. All implants were withdrawn on day 23 of the oestrous cycle. (a) Patterns of growth of the first wave dominant follicles in T1, categorized according to their fate, ovulation $(\mathrm{O}-\mathrm{O} ; n=5)$ or atresia ( - ; $n=3$ ); ( $\square-\square$ ) pattern of growth of the second wave dominant follicle in T1 $(n=3)$. Patterns of growth of the first ( $\triangle-$ $\Delta$ ) and second ( $\boldsymbol{\Delta} \mathbf{\Delta}$ ) wave dominant follicles in T2 are also shown. (b) Concentrations of plasma oestradiol of cows in T1, classified as to whether they ovulated the first wave dominant follicle $(\mathrm{O}-\mathrm{O} ; n=5$ ) or developed a second follicular wave ( $n=3)$. ( $\triangle \longrightarrow \triangle$ ) Plasma concentrations of oestradiol for $\mathrm{T} 2$.

day 7 of the oestrous cycle. This follicle was the subsequent ovulatory follicle in five of eight cows in T1 but in none of the eight cows in T2 $(P<0.01)$. In those animals in which the first dominant follicle was not ovulatory (three of eight in $\mathrm{T} 1$ and all cows in T2; $P<0.05$ ), a second (ovulatory) dominant follicle was detected on day $24.6 \pm 0.3$ in T1 $(n=3)$ and $20.6 \pm 1.2$ in T2 ( $n=8 ; P<0.01$ ). Growth patterns (days 7 to ovulation) of the first dominant follicles were different between experimental treatments $(P<0.001$; Fig. 1a). Analyses of the data revealed that the differences between treatments resided in the period between days 18 to ovulation. During this phase (between day 18 and day 23), the dominant follicle in T2 stopped growing and underwent a reduction in size, whereas the average size of dominant follicles in TI did not show a reduction in size $(P<0.003)$. As expected, the profile of development of the first dominant follicle in $\mathrm{T} 1$ differed depending on whether it was ( $n=5$; single wave) or was not $(n=3$; double wave) the ovulatory follicle. The average duration of the oestrous cycles did not differ between treatments $(\mathrm{T} 1=$ $24.5 \pm 1.2$ days and $\mathrm{T} 2=25.7 \pm 0.2$ days). However, the different number of waves detected in $\mathrm{T} 1$ did affect the duration of the oestrous cycles. The average duration of the oestrous cycle for cows in T1 in which the first dominant follicle was ovulatory ( $n=5$ ) was $22.6 \pm 1.2$ days (range 18 to 24 days) compared with $27.7 \pm 0.7$ days (range 27 to 28 days) for those cows that had two follicular waves $(n=3)$. Time of onset of oestrus was similar for cows in T2 (two cows on day 25 and six cows on day 26) following the selection of a second wave dominant follicle.

The average size of the preovulatory follicle on the last measurement before ovulation was $19.4 \pm 2.4$ and $16.5 \pm$ $0.7 \mathrm{~mm}$ for $\mathrm{T} 1$ and $\mathrm{T} 2$, respectively (no significant difference). Within $\mathrm{T} 1$, the average preovulatory follicle size was $26.4 \pm$ $1.3 \mathrm{~mm}(n=5)$, when the first dominant follicle was the only ovulatory follicle. However, if the original dominant follicle became atretic then the preovulatory size of the second wave follicle (three cows) was $12.4 \pm 0.8 \mathrm{~mm}(P<0.01, n=5$ ovulatory follicles). Although only three cows developed a second follicular wave in $\mathrm{T} 1$, two of these cows ovulated two follicles that originated in the second follicular wave. One cow in T2 had a double ovulation, with the new (second follicular wave) and the previous dominant follicle (first follicular wave) ovulating. One cow in T1 (period 1) was in oestrus on day 18 and ovulated a persistent first wave dominant follicle by day 20 of the oestrous cycle, when the Norgestomet implant was still in place.

The differences in the number of follicular waves during the period between 18 and 26 days affected follicular dynamics (Table 1). The analysis of follicular dynamics, in terms of number of follicles within size classes, detected treatment $x$ day interactions for class II $(P<0.01)$ and class III follicles $(P<0.05)$. No differences between treatments were detected in class I (3-4 mm) follicles. The number of class II follicles $(5-9 \mathrm{~mm})$ increased between day 24 and day 26 in T1 compared with days $20-22$ in $T 2$. These increases coincided with the loss of dominance of the first wave dominant follicle in the three cows of $\mathrm{T} 1$ and seven cows of $\mathrm{T} 2$. The remaining cow in $\mathrm{T} 2$ developed the second follicular wave by day 12 of the experimental oestrous cycle.

\section{Oestradiol concentrations}

In both treatment groups, the plasma concentration of oestradiol increased from day 8 and was high $\left(>12 \mathrm{pg} \mathrm{ml}^{-1}\right)$ at least until day 18 (Fig. 1b). After day 18, concentrations of oestradiol remained high until oestrus in T1 $\left(>12 \mathrm{pg} \mathrm{ml}^{-1}\right)$. Although plasma concentrations of oestradiol declined after day 18 in T1 cows with a persistent first wave ovulatory follicle, concentrations of oestradiol could still induce oestrus. In those animals of TI that failed to ovulate the initial dominant follicle $(n=3)$, a decline in plasma concentrations of oestradiol was observed from day 16 of the cycle. In T2 (where the initial Norgestomet implant was replaced by a new implant on day 18), plasma concentrations of oestradiol declined rapidly after day 18 and remained low $\left(<5 \mathrm{pg} \mathrm{ml}^{-1}\right)$ until development of the new preovulatory dominant follicle. The mean plasma concentration of oestradiol on the day of oestrus was $13.5 \pm 2.8 \mathrm{pg} \mathrm{ml}^{-1}$ for 
Table 1. Mean number of class I $(3-4 \mathrm{~mm})$, II $(5-9 \mathrm{~mm})$ and III (>9 mm) follicles in nonlactating Holstein cows that received a prostaglandin $\mathrm{F}_{2 \alpha}$ injection and a Norgestomet implant on day 8 of the oestrous cycle

\begin{tabular}{|c|c|c|c|c|c|c|c|c|}
\hline \multirow{2}{*}{$\begin{array}{l}\text { Day of } \\
\text { oestrous } \\
\text { cycle }\end{array}$} & \multicolumn{2}{|c|}{$\begin{array}{l}\text { Number } \\
\text { of cows }\end{array}$} & \multicolumn{2}{|c|}{$\begin{array}{l}\text { Class I } \\
(3-4 \mathrm{~mm})\end{array}$} & \multicolumn{2}{|c|}{$\begin{array}{c}\text { Class II } \\
(5-9 \mathrm{~mm})^{\mathrm{a}}\end{array}$} & \multicolumn{2}{|c|}{$\begin{array}{c}\text { Class III } \\
(>9 \mathrm{~mm})^{b}\end{array}$} \\
\hline & $\mathrm{T} 1$ & $\mathrm{~T} 2$ & $\mathrm{~T} 1$ & $\mathrm{~T} 2$ & $\mathrm{~T} 1$ & $\mathrm{~T} 2$ & $\mathrm{~T} 1$ & $\mathrm{~T} 2$ \\
\hline 7 & 8 & 8 & 3.7 & 2.1 & 2.8 & 2.8 & 1.0 & 1.0 \\
\hline 8 & 8 & 8 & 4.1 & 2.1 & 1.5 & 1.5 & 1.0 & 1.0 \\
\hline 10 & 8 & 8 & 8.0 & 11.1 & 0.2 & 0.5 & 1.0 & 1.0 \\
\hline 12 & 8 & 8 & 7.7 & 10.0 & 0.2 & 0.5 & 1.0 & 1.1 \\
\hline 14 & 8 & 8 & 9.5 & 10.2 & 0.2 & 0.8 & 1.0 & 1.1 \\
\hline 16 & 8 & 8 & 12.1 & 17.1 & 0.6 & 0.2 & 1.0 & 1.1 \\
\hline 18 & 8 & 8 & 9.0 & 13.5 & 0.8 & 0.2 & 1.0 & 1.1 \\
\hline 20 & 7 & 8 & 12.0 & 12.7 & 1.0 & 2.3 & 1.0 & 1.1 \\
\hline 22 & 7 & 8 & 10.0 & 12.5 & 1.5 & 6.1 & 1.0 & I.1 \\
\hline 24 & 3 & 8 & 11.8 & 13.0 & 3.3 & 3.3 & 1.0 & 1.8 \\
\hline 26 & 3 & 6 & 10.9 & 8.0 & 7.0 & 2.3 & 2.3 & 2.0 \\
\hline
\end{tabular}

${ }^{\circ} P<0.01$ for days 18 to 26 treatment $\times$ day interaction.

${ }^{b} p<0.05$ for days 18 to 26 treatment $x$ day interaction.

T1: Norgestomet implant $(6 \mathrm{mg})$ and prostaglandin $F_{2 a}$ injection $(25 \mathrm{mg})$ on day 8 of the cycle.

T2: As T1 but a new implant was inserted on day 18 of the cycle. All implants were removed on day 23 .

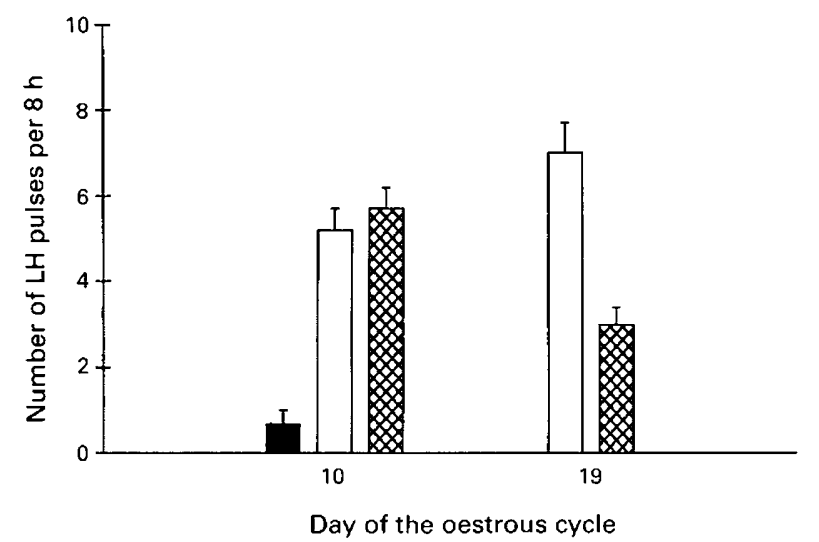

Fig. 2. Luteinizing hormone (LH) pulse frequency during $8 \mathrm{~h}$ periods on days 10 and 19 for $\mathrm{T} 1(\square)$ and $\mathrm{T} 2$ ( cows that received a PGF $2 \alpha$ injection $(25 \mathrm{mg}$ ) on day 8 and a Norgestomet implant $(6 \mathrm{mg})$ between days 8 and 23 (T1). In T2, the original implant was replaced by a new unit on day 18. A group of control animals on day 10 of a natural oestrous cycle $(\boldsymbol{\square} ; n=3$ ) also are shown.

T2 cows $(n=8)$. For T1 cows that developed a second follicular wave $(n=3)$, plasma concentrations of oestradiol on the day of oestrus were $7.3 \pm 1.4 \mathrm{pg} \mathrm{ml}^{-1}$.

\section{Luteinizing hormone dynamics}

LH pulse frequency on day 10 of the oestrous cycle (Fig. 2) was different between treated (T1 and T2) and control animals
$(5.2 \pm 0.5$ and $5.7 \pm 0.5$ per $8 \mathrm{~h}$ for $\mathrm{T} 1$ and $\mathrm{T} 2$, respectively, versus $0.7 \pm 0.3$ per $8 \mathrm{~h}$ for controls; $P<0.001$ ). On day 19 (one day after the initial Norgestomet implant was replaced with a new implant in T2), $\mathrm{LH}$ pulse frequency was greater in $\mathrm{T} 1$ than in $\mathrm{T} 2(7.0 \pm 0.7$ versus $3.0 \pm 0.4$, respectively). A treatment (TI and T2) $\times$ day (days 10 and 19) interaction for LH pulse frequency was detected $(P<0.001)$. No differences in LH pulse amplitude were detected $(0.7 \pm 0.1$ and $1.0 \pm 0.3$ (T1) and $0.8 \pm 0.3$ and $0.6 \pm 0.2 \mathrm{ng} \mathrm{ml}^{-1}$ (T2) on days 10 and 19, respectively; $P>0.1$ ). LH pulse amplitude for the control group was $3.5 \pm 0.7 \mathrm{ng} \mathrm{ml}^{-1}$.

\section{Intervening oestrous cycles}

During the spontaneous intervening oestrous cycles, five cows had three follicular waves (three cows from TI and two cows from T2; Fig. 3a) and three cows had two follicular waves (one cow from T1 and two cows from T2; Fig. 3b). In those cycles with three waves $(n=5)$, the respective dominant follicles were identified on days $2.2 \pm 0.5,11.0 \pm 0.8$ and $17.0 \pm 0.4$ and reached maximum sizes on days $7.4 \pm 0.4$ $(16.6 \pm 1.4 \mathrm{~mm}), 15.0 \pm 0.9(13.0 \pm 0.5 \mathrm{~mm})$ and $22.2 \pm 0.2$ (14.2 $\pm 1.0 \mathrm{~mm}$ ), for the first, second and third (ovulatory) follicular waves, respectively. In the intervening oestrous cycles with two follicular waves $(n=3)$, the first wave dominant follicle was identified on day $2.6 \pm 0.7$ and reached maximum size $(16.7 \pm 0.9 \mathrm{~mm})$ on day $8.7 \pm 0.7$. The second wave dominant follicle was first detected on day $15.3 \pm 1.8$ and reached maximum size $(18.7 \pm 0.9 \mathrm{~mm})$ on the day of oestrus $(22.0 \pm 1.1)$. Overall mean duration of the intervening oestrous cycle was $22.1 \pm 0.4$ days, and did not differ between oestrous cycles comprising two or three follicular waves $(22.0 \pm 1.1$ and $22.2 \pm 0.2$ days, respectively).

The hormonal profiles of progesterone and oestradiol during the intervening oestrous cycles (Fig. 3c, d) were characterized by increasing plasma concentrations of progesterone during early stages of the oestrous cycle. From day 8 onwards, plasma concentrations of progesterone ranged from 5.5 to $8.5 \mathrm{ng} \mathrm{ml}^{-1}$ and reached peak values between days 15 and 18. Oestradiol concentrations increased at the early stages of the oestrous cycle (days 4 to $6 ; 5 \mathrm{pg} \mathrm{m}^{-1}$ ) and returned to a basal concentration throughout the luteal phase. Plasma concentrations of oestradiol increased during the following luteolytic and preovulatory phase of the cycle.

\section{Discussion}

The absence of ovulations between day 8 and day 18 indicates that sufficient progestin was released from the implant of Norgestomet to prevent ovulation of the dominant follicle until at least day 18 (one cow in T1 was in oestrus on day 18). If no implant had been inserted coincident with injection of $\mathrm{PGF}_{2 \alpha}$ on day 8 of the oestrous cycle, ovulation of the day 8 dominant follicle would have occurred (Kastelic et al., 1990; Savio et al., 1990b). Although ovulation was prevented up to day 18, there was insufficient progestin activity to maintain a strong negative feedback on LH pulse frequency in a manner comparable to that of the luteal phase of a normal oestrous cycle (high amplitude, low pulse frequency; Rahe et al., 1980, Walters et al., 1984; 
(a)

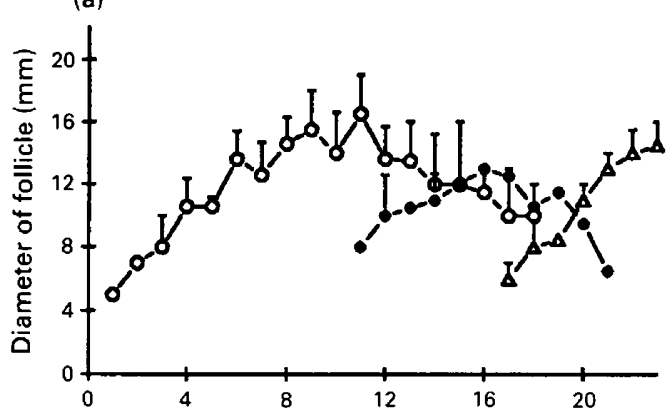

(c)

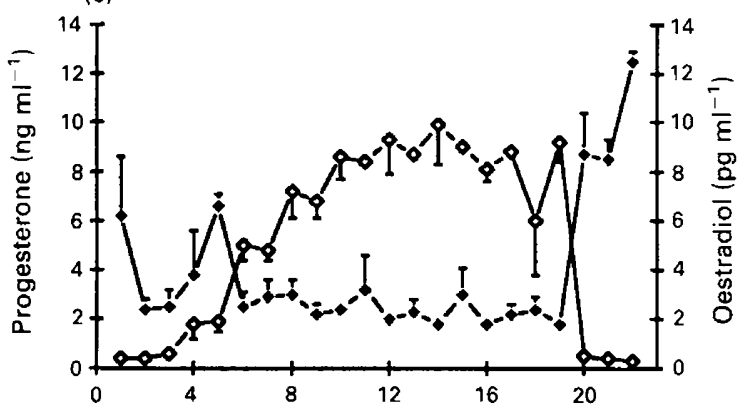

(b)

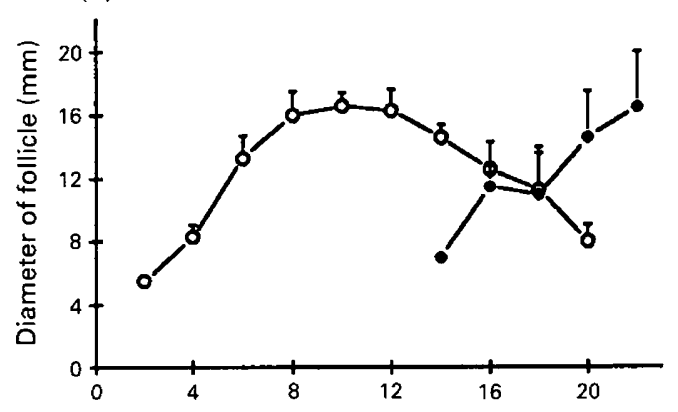

(d)

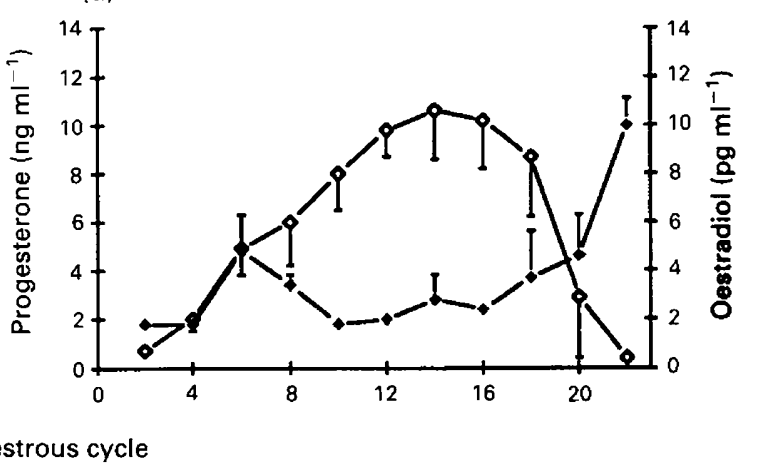

Fig. 3. Follicular development and hormone concentrations during the natural intervening oestrous cycles. (a) and (b) show the patterns of development of the first $(\mathrm{C}-\mathrm{O})$, second $(-\triangle)$ ) and third $(\triangle-\triangle)$ wave dominant follicles in cows that had three $(n=5)$ or two follicular waves $(n=3)$, respectively. (c) and (d): plasma concentrations of $(\diamond)$ progesterone and $(\diamond)$ oestradiol for cows that had three or two follicular waves during the intervening oestrous cycle, respectively.

Schallenberger et al., 1985a). Low concentrations of progesterone or Norgestomet originating from intravaginal devices or implants have resulted in high frequency of LH pulses (Ireland and Roche, 1982; Roberson et al., 1989; Kojima et al., 1990) in agreement with results of the present study.

The intervals from the time of implant insertion (day 8, T1 and T2) or replacement (day 18, T2) to the blood sampling for LH assay (days 10 and 19 after oestrus) were 48 and $24 \mathrm{~h}$, respectively. Increased LH pulse frequency from days 10 to 19 in T1 (5.2 and 7.0 LH pulses per $8 \mathrm{~h}$, respectively) suggest either a diminished negative effect of the declining progestin concentrations or an increased hypothalamic sensitivity to increasing oestradiol concentrations or a combination of both effects. By contrast, in $\mathrm{T} 2$ there was a reduction in LH pulse frequency after the change of implant on day $18(5.7$ versus $3.0 \mathrm{LH}$ pulses per $8 \mathrm{~h}$ on days 10 and 19 , respectively). If similar blood concentrations of Norgestomet on days 10 and 19 in T2 are assumed, a potential differential sensitivity of the hypothalamichypophysial-ovarian axis, which resulted in changes in $\mathrm{LH}$ secretion, is indicated. Since plasma concentrations of oestradiol on day 18 were comparable and high in both treatments $\left(>20 \mathrm{pg} \mathrm{ml}^{-1}\right)$, the reduction in LH pulse frequency in T2 is, probably, indicative of an intensified negative effect of Norgestomet from the new implant on LH secretion. However, since Norgestomet concentrations in plasma were not measured, changes in sensitivity to the negative feedback effect of Norgestomet concentrations in plasma cannot be delineated.

Continued follicular growth after day 18 and oestradiol production and ovulation of five of eight first wave dominant follicles are indicative of sustained follicular function supported by preovulatory-like patterns of LH secretion detected on day 19 in T1. The lower LH pulse frequency detected on day 19 in T2 was therefore probably the main cause of follicular atresia and cessation of oestrogen production after the change of implants on day 18 . The possibility of low LH pulse frequency as a cause of atresia of dominant follicles in cattle agrees with data of Glencross (1987) who reported an immediate decline in plasma oestrogen concentrations after cessation of hourly injections of gonadotrophin-releasing hormone $(\mathrm{GnRH})$ to heifers in the luteal phase or in heifers supplemented with exogenous progesterone.

The large dominant follicles of T2 underwent atresia after day 20 as indicated by a decrease in size, loss of oestrogenic activity, recruitment of a new follicular wave and a failure of most first wave follicles to ovulate subsequently. In contrast, five of eight $\mathrm{T} 1$ cows sustained growth and oestrogenic activity of the first wave dominant follicle that led to an ovulation. Large dominant follicles at day 18 of the T2 experimental cycle appear to be near the threshold of their lifespan and appear very sensitive to changes in LH secretion. This apparent threshold of follicular health was also evident in $\mathrm{T} 1$ cows, since three of eight cows experienced a spontaneous decrease in plasma oestradiol, had large dominant follicles that decreased in size, their dominance subsiding since a second follicular wave ensued leading to ovulation.

Complete suppression of class II $(5-9 \mathrm{~mm})$ follicles was observed during the periods of extended dominance of the first wave dominant follicle (Table 1 ). Increased numbers of class II follicles were observed only during the development of a new 
follicular wave (day 20 and 24 for T2 and T1, respectively) after the previous dominant follicle had lost its dominance. If the original, sustained dominant follicle subsequently ovulated (five cows in TI), there was no change in the number of class II follicles. Thus, dominant follicles that developed under the present experimental conditions were true, fully developed, first wave dominant follicles of the oestrous cycle with an extended lifespan.

The extended period of growth of a single follicle, as detected in the present experiment, differs substantially from the pattern observed in the intervening cycles and in known patterns of follicular development reported for cycling heifers and cows in the presence of a corpus luteum (Savio et al., 1988, 1990a; Sirois and Fortune, 1988; Knopf et al., 1989; Driancourt et al., 1991) but is comparable to the development of follicular cysts during the postpartum period (Savio et al., 1990c) and to longer oestrous cycles (Sirois and Fortune, 1990).

Under physiological conditions, the first wave dominant follicle in cattle is ovulatory only in short ovarian cycles (9-12 days) following periods of anoestrus in postpartum cows (Savio et al., 1990a; Murphy et al., 1990). The cessation of growth for non-ovulatory dominant follicles, which develop during normal luteal phases of the oestrous cycle (Savio et al., 1988a, 1990a; Sirois and Fortune, 1988; Knopf et al., 1989; Driancourt et al., 1991) and early pregnancy (Ginther et al., 1989b; Savio et al., 1990a; Thatcher et al., 1991) may therefore be due to a lack of adequate LH support to sustain follicular growth and function. Continued follicular growth and oestrogen production in heifers treated with hourly $\mathrm{GnRH}$ pulses during the luteal phase (Glencross, 1987) supports this hypothesis.

Follicular development in cattle is thought to be regulated primarily by gonadotrophic hormones (Richards, 1980; Ireland, 1987; Ireland and Roche, 1987; Lucy et al., 1992). This study indicates that $\mathrm{LH}$ is critical for continued follicular growth. However, terminal stages of antral follicular development and follicular hierarchy in monovular species may be regulated at the ovarian level by the presence of an active dominant follicle. Turnover of dominant follicles which permits development of new follicular waves appears to be determined by the inability of the dominant follicle to continue growing and suppressing the growth of other follicles. Decreased availability of $\mathrm{LH}$ appears to contribute to the turnover of the dominant follicle.

The concept that LH exerts a regulatory effect on final follicular development is supported by several physiological observations. Follicular development during the early postpartum period in dairy cows is characterized by development of follicles $\leqslant 8 \mathrm{~mm}$ until development of the first postpartum dominant follicle (Savio et al., 1990c). Murphy et al. (1990) indicated that suckling beef cows developed two or three non-ovulatory dominant follicles during the postpartum period before the ovulatory follicle, and that each non-ovulatory dominant follicle became progressively larger. Since FSH appears not to be a limiting factor under these physiological conditions, limited follicular growth may be a consequence of an inadequate follicular content of androgens due to depressed LH secretion during late pregnancy (Little et al., 1982; Schallenberger et al., 1985b) and a suckling-induced reduction in postpartum LH secretion which diminishes with increased days post partum (Williams et al., 1982). Decreased availability of LH persists during the early postpartum period (Fernandes et al., 1978; Weesner et al., 1987).
In addition, growth and ovulation of follicles in prepubertal heifers can be achieved by repeated injections of $\mathrm{LH}$ (Tortonese et al., 1990). Collectively, these observations support the concept that LH regulates the growth and dominance of dominant non-ovulatory and ovulatory follicles in cattle.

In conclusion, turnover of ovarian follicles during the oestrous cycle in cattle is regulated by the concentration of progesterone in plasma acting via a negative feedback effect on LH secretion. Low frequency of LH pulses characteristic of the luteal phase is not sufficient to maintain continued growth and function of the dominant follicle. It is hypothesized that inadequate thecal androgen secretion limits subsequent granulosa cell function required for terminal follicular development and that owing to this functional limitation, the dominant follicle can no longer suppress the growth of other follicles, and a new follicular wave then develops. Conversely, the removal of the negative progesterone feedback supports continued growth and dominance of the follicle due to increased availability of $\mathrm{LH}$.

This is Florida Agricultural Experiment Station Journal Series No. R-02554.

\section{References}

Abeyawardene SA and Pope GS (1987) The involvement of progesterone and luteinizing hormone in the termination of the post-ovulatory rise in plasma estradiol-17 beta concentrations in cattle Animal Reproduction Science 15 27-36

Badinga L, Driancourt MA, Savio JD, Wolfenson D, Drost M, de la Sota RL and Thatcher WW (1992) Endocrine and ovarian responses associated with the first wave dominant follicle in cattle Biology of Reproduction $47871-873$

Driancourt MA, Thatcher WW, Terqui M and Andrieu D (1991) Dynamics of ovarian follicular development in cattle during the estrous cycle, early pregnancy and in response to PMSG Domestic Animal Endocrinology 8 209-22I

Fernandes LC. Thatcher WW, Wilcox CJ and Call EP (1978) LH release in response to $\mathrm{GnRH}$ during the postpartum period of dairy cows Journal of Animal Science $46443-448$

Findlay JK, Xiao S and Shukovski L (1990) Role of inhibin-related peptides as intragonadal regulators Reproduction, Fertility and Development 2 205-218

Ginther, OJ, Kastelic JP and Knopf L (1989a) Composition and characteristics of follicular waves during the bovine oestrous cycle Animal Reproduction Science 20 187-200

Ginther OJ, Knopf L and Kastelic JP (1989b) Ovarian follicular dynamics in heifers during early pregnancy Biology of Reproduction 41 247-254

Glencross RG (1987) Effect of pulsatile infusion of gonadotrophin-releasing hormone on plasma oestradiol-17 $\beta$ concentrations and follicular development during naturally and artificially maintained high levels of plasma progesterone in heifers Journal of Endocrinology 112 77-85

Goodman AL and Hodgen GD (1983) The ovarian triad of the primate menstrual cycle Recent Progress in Hormone Research 39 1-73

Ireland JJ (1987) Control of follicular growth and development Journal of Reproduction and Fertility Supplement 34 39-54

Ireland JJ and Roche JF (1982) Effect of progesterone on basal LH and episodic LH and FSH secretion in heifers Joumal of Reproduction and Fertility 64 295-302

Ireland JJ and Roche JF (1987) Hypotheses regarding development of dominant follicles during bovine oestrous cycles. In Follicular Growth and Ovulation Rate in Farm Animals pp I-I7 Eds JF Roche and D O'Callaghan. Martinus Nijhoff Publishers, The Hague

Kastelic JP, Knopf L and Ginther OJ (1990) Effect of day of prostaglandin F2alpha treatment on selection and development of the ovulatory follicle in heifers Animal Reproduction Science 23 169-180

Knickerbocker J], Thatcher WW, Bazer FW, Drost M, Barron DH, Fincher KB and Roberts RM (1986) Proteins secreted by Day 16 to 18 conceptuses extend corpus luteum function in cows Joumal of Reproduction and Fertility 77 $381-391$ 
Knopf L, Kastelic JP, Schallenberger E and Ginther OJ (1989) Ovarian follicular dynamics in heifers: test of the two wave hypothesis by ultrasonically monitoring individual follicles Domestic Animal Endocrinology 6 111-119

Kojima N, Stumpf TT, Cupp AS, Werth LA, Roberson MS, Wolfe MW, Kittok RJ and Kinder JE (1990) Effect of progestin and two levels of progesterone (P4) on secretion of luteinizing hormone $(\mathrm{LH})$ and 17-beta estradiol (E2) Journal of Animal Science 68 (Supplement 1) 440-441 (Abstract 503)

Little DE, Rahe CH, Fleeger JL and Harms PG (1982) Episodic release of LH during gestation in the cow Joumal of Reproduction and Fertility 66 687-690

Lucy MC, Staples CR, Michel FM and Thatcher WW (1991) Effect of feeding calcium soaps to early postpartum dairy cows on plasma prostaglandin $F_{2 a^{\prime}}$ luteinizing hormone, and follicular growth Journal of Dairy Science $\mathbf{7 4}$ 483-489

Lucy MC, Savio JD, Badinga L, de la Sota RL and Thatcher WW (1992) Factors that affect ovarian follicular dynamics in cattle Journal of Animal Science $\mathbf{7 0}$ $3615-3626$

Murphy MG, Boland MP and Roche JF (1990) Pattem of follicular growth and resumption of ovarian activity in post-partum beef suckler cows Journal of Reproduction and Ferfility $90523-533$

Rahe CH, Owens RE, Newton HJ, Fleeger JL and Harms PG (1980) Pattern of plasma luteinizing hormone in the cyclic cow: dependence upon the period of the cycle Endocrinology 107 498-503

Richards JS (1980) Maturation of ovarian follicles: actions and interactions of pituitary and ovarian hormones on follicular cell differentiation Physiological Reviews 60 51-89

Roberson MS, Wolfe MW, Stumpf TT, Kittok RJ and Kinder JE (1989) Luteinizing hormone secretion and corpus luteum function in cows receiving two levels of progesterone Biology of Reproduction 41 997-1003

SAS (1987) SAS User's Guide: Statistics. Statistical Analysis System Institute, Inc. Cary, NC

Savio JD, Keenan L, Boland MP and Roche JF (1988) Pattern of growth of dominant follicles during the oestrous cycle of heifers Joumal of Reproduction and Fertility $83663-671$

Savio JD, Boland MP and Roche JF (1990a) Development of dominant follicles and ovarian activity in the post-partum period of dairy cows Journal of Reproduction and Fertility 88 581-591
Savio JD, Boland MP, Hynes N, Mattiacci MR and Roche JF (1990b) Will the first dominant follicle of the estrous cycle ovulate following luteolysis on day $7 ?$ Theriogenology $33677-688$

Savio JD, Boland MP, Hynes N and Roche JF (1990c) Resumption of follicular activity in the early post-partum period of dairy cows Journal of Reproduction and Fertility 88 569-579

Schallenberger E, Schondorfer AM and Walters DL (1985a) Gonadotrophins and ovarian steroids in cattle. I. Pulsatile changes of concentrations in the jugular vein throughout the oestrous cycle Acta Endocrinologica 108 312 -321

Schallenberger E, Ramp J and Walters DL (1985b) Gonadotrophins and ovarian steroids in cattle. II. Pulsatile changes of concentrations in the jugular vein throughout pregnancy Acta Endocrinologica 108 322-330

Sirois J and Fortune JE (1988) Ovarian follicular dynamics during the estrous cycle monitored by real-time ultrasonography Biology of Reproduction 39 308-317

Sirois J and Fortune JE (1990) Lengthening of the bovine estrous cycle with two levels of exogenous progesterone: a model for studying ovarian follicular dominance Endocrinology $127916-925$

Thatcher WW, Driancourt MA, Terqui M and Badinga L (1991) Dynamics of ovarian follicular development in cattle following hysterectomy and during early pregnancy Domestic Animal Endocrinology 8 223-234

Tortonese DJ, Lewis PE, Papkoff $\mathrm{H}$ and Inskeep EK (1990) Role of the dominant follicle and the pattern of oestradiol in induction of preovulatory surges of LH and FSH in prepubertal heifers by pulsatile low doses of LH Journal of Reproduction and Fertility 90 127-135

Walters DL, Schams D and Schallenberger E (1984) Pulsatile secretion of gonadotrophins, ovarian steroids and ovarian oxytocin during the luteal phase of the estrous cycle in the cow Journal of Reproduction and Fertility 71 479-491

Weesner GD, Norris, TA, Forrest DW and Harms PG (1987) Biological activity of luteinizing hormone in the peripartum cow: least activity at parturition with an increase throughout the postpartum interval Biology of Reproduction $37851-858$

Williams GL, Kotwica J, Slanger WD, Olson DK, Tilton JE and Johnson LJ (1982) Effect of suckling on pituitary responsiveness to gonadotrophin-releasing hormone throughout the early postpartum period of beef cows Journal of Animal Science 54 594-602 